\title{
Law Enforcement of SMEs Licensing in Empowerment of People's Economy Connected to Regional Autonomy in North Sumatra, Indonesia
}

\author{
Mukidi $^{1}$, Nelly Azwarni Sinaga ${ }^{2}$, Nelvitia Purba ${ }^{3}$ and Rudy Pramono ${ }^{4}{ }^{*}$ \\ ${ }^{1}$ Universitas Islam Sumatera Utara; ${ }^{2}$ Sekolah Tinggi IImu Ekonomi Sibolga; ${ }^{3}$ Universitas Muslim Nusantara Al \\ Washliyah; ${ }^{4}$ Pelita Harapan University, Indonesia
}

\begin{abstract}
SME licensing aims to encourage the empowerment of the people's economy through improving the quality of licensing services in the regional autonomy government and for better chances in the future in North Sumatra Province. The research method used is normative legal research (juridical normative), juridical sociology, and empirical to find the truth related to the enforcement of SME licensing laws that have been stipulated in the regulations. Result of this study, the process for obtaining SME licensing in North Sumatra has been regulated through the One-Stop Integrated Licensing Service Agency based on the Minister of Home Affairs Regulation followed by Governor, Regent, and Mayor regulations through regional regulations. In the implementation, it will be carried out using technology systems and facilities or still manual. From the actual conditions, licensing services are still problematic so that to achieve the goal of law enforcement in empowering the people's economy or even to improve the economy of the community is not yet optimal, because the implementation of regulations has not been implemented properly and correctly so that the people applying for permits still have difficulty obtaining business licenses. From the results of the delegation of the authority of the regional head to the BPPTSP, it has not been fully implemented, there are still other offices that accept delegations so that permit applicants find it difficult and convoluted and their implementation overlaps in the difficult bureaucracy, finally the timeliness and expenditure of costs are not as expected.
\end{abstract}

Keywords: Law enforcement, licensing, SME empowerment.

\section{INTRODUCTION}

The status of a permit as a State Administrative Decree is a free decision, thus that in its stipulation a license is not only based on written administrative law norms but also based on unwritten legal norms, namely: General principles of Good Governance (Sulistiyani and Hardianto, 2019). Result of survey Ombudsman of the Republic of Indonesia representative of North Sumatra December 25, 2013, and also concluded: Service Licensing Sumatera North Provincial Government 2013 included in the zone of the red or the value of the service permit its entry in the category below a score of 500 is bad (http://analisadaily.net/news).

From the survey results in the above authors closer look at reality in question, with a part of the District and municipalities in the Province of North Sumatra on condition of law enforcement permit Small and Medium Enterprises (SMEs) in the city of Medan, Binjai, Deli Serdang Regency and Langkat as benchmarks of government closest to the capital of North Sumatra Province in empowering people's economy in the region carried out self-government.

*Address correspondence to this author at the Pelita Harapan University, Indonesia; E-mail: rudy.pramono@uph.edu
The pitch so it is now in the process of obtaining permits small and medium enterprises (SMEs) are still problematic in bureaucracy in the field suppose in the implementation of the licensing service following the procedures specified then it will be able to advance the business both in economic small and medium enterprises. On the other hand fixed violations occur in either the financial or administrative settlement originating from the service department authorized to issue permits therefore law enforcement licensing held by governments district and City at Provincial North Sumatera must be upheld.

Law enforcement efforts are only one element of the whole problem as a rule of law that aspires to uphold and realize social justice for all Indonesian people. The law may not be upheld if the law itself does not or does not reflect the feelings or values of justice that live in the community. The law is impossible to guarantee justice if the material is largely a legacy of the past that is no longer in line with the demands of the times, meaning that the problems faced are not only related to law enforcement efforts but also legal reform or new lawmaking. Therefore, four important functions require careful attention, namely: the legislation of law or 'law and rulemaking), socialization, dissemination and even the culture of law (socialization and promulgation of law), and law enforcement (Hartono, 2007).

(Rahardjo in Imaniyati, 2007) with a populist economy that is more inclined towards developing an 
Islamic economy as a democratic economy, and other popular economic thinkers, all of whom emphasize issues of ethics and justice. The people's economy is an alternative to the global economic order which tends to lead to a liberalist, capitalist economic order. The focus of alternative economic approaches is not only how prosperity is increased but also how production and consumption are distributed. In other words, profit sharing and employee participation or sharing of benefits and risks. that's what determines " who gets what, when, how and how much". Problems can only be understood through an approach that is different from the liberal one.

From the description above, the importance of licensing law enforcement must continue to be improved because there is still a tendency that it is difficult for the community to obtain a license to run a business, the difficulty of borrowing bureaucracy of capital from a comparison with the stipulated conditions, including evidence of a business license that is managed and considered by the regional government not able to socialize well to the community so that people are hesitant to register a license for business designation. Government both provincial, district and city can optimize to get a revenue of the sector of licensing means that the income of local finance better local government is expected to pay attention to the progress of the social economy. It is very supportive for populist economic empowerment to create employment and community development efforts so as I ore developed and developing, so that improve the people be better. Enforcement of licensing law will have an impact on the economic progress of democracy in the province of North Sumatra, supported by at least by the Office services integrated licensing one door, Department of Cooperatives and SMEs, D carbuncle of Industry and Trade, the Department of Revenue and the Department of Culture and Tourism.

It is hoped that the results of this study can provide an overview of the law enforcement of SME licensing in North Sumatra Province related to the principle of regional autonomy. So that it can be designed and changes for the better in the future.

Based on the description above authors are interested to study the permit law enforcement SME's economic empowerment populist associated with as regional autonomy in the province of North Sumatra and as samples in meticulous in the city of Medan, Kota Binjai, Deli Serdang, and Langkat.

\section{RESEARCH METHODS}

\section{Short Methods of Research}

Research methods used in the study are the normative legal research (Jauhari, 2013). The method of thinking used is the deductive method of thinking (a way of thinking in drawing conclusions drawn from something general which has been proven to be correct and the conclusion is aimed at something specific) (Sedarmayanti and Hidayat, 2003). The normative legal research paradigm used is the paradigm of Positivism Law (Anwar and Adang, 2010), the research method is Juridical-Normative. Concerning normative research, several approaches will be used (Ibrahim, 2003).

\section{a. Statute Approach}

Approach legislation (statute approach) is an approach that is conducted on a variety of legal rules related to law enforcement, management of Regions such as Law No. 23 Year 2014 about Autonomous Region, Act No. 17 of 2003, Regarding State Finance, Law Number 33 of 2004 concerning the Balance between Central Government and Regional Government, as well as Government Regulation of the Republic of Indonesia Number 58 of 2005 concerning Regional Financial Management, policies and strategies for developing small and medium enterprises of Bank Indonesia after Law no. 23/1999. Law No. 28/1999 concerning the Implementation of a State that is Clean and Free from Corruption, Collusion, and Nepotism, that states the principles of clean governance.

\section{b. Concept Approach}

The conceptual approach is used to understand the concepts of Law enforcement, licensing bureaucracy, legal certainty for Small and Micro Business entrepreneurs, Regional Financial Management $h$.

According to Johnny Ibrahim, in legal research are multiple approaches, that statue approach, the conceptual approach, analytical approach, the comparative approach, the historical approach, a philosophic approach, and a case approach. What is used in this paper is the statutory approach, analytical approach, conceptual approach, and case approach (Ibrahim, 2003).

\section{c. Research Specifications}

This study is legal law research that is normative juridical and sociological and empirical. In obtaining 
primary data, observations and interviews were carried out with officials related to licensing law enforcement on the empowerment of the people's economy in the Micro and Small Business sector (UMK) at the Ministry of Action and related agencies in North Sumatra Province.

\section{Data Collection Technique}

Data collection techniques are carried out through data analysis which can be obtained in statutory regulations, textbooks, journals, research results, encyclopedia, bibliographies, cumulative indexes, and others. Data collection techniques with this approach are carried out on various literature (libraries). This technique can be done through an inventory of various regulatory products which are then carried out by recording in detail (considered complete) as well as classifying various products of legislation that have relevance to the research material.

A uga carry them through Research Library ( library research ), ie the research literature, which in this study the authors collected data from the literature and studying the books of the technical guidelines and theories that can be used as research material Dissertation and material support in research.

Furthermore Field Research (Fieldwork Research), namely direct research into the field by:

1. Observation, collecting data by making direct observations in the field b. Interviews, observations through direct interviews with the informant,

2. Documentation, data collection is carried out to obtain secondary data in the form of documents or archives, and scientific papers relevant to this research.

\section{a. Data Analysis Method}

The methods of data analysis used in this study is the descriptive qualitative method, which describes and analyzes the data that has been obtained and further elaborated in the form of explanation .

\section{DISCUSSION}

Conditions Implementation of Licensing SMEs in Binjai City, Langkat, And Medan in North Sumatra Province. In implementing licensing is necessary to reform the bureaucracy per permit an effort because it is a policy that must be taken to renew the process of service delivery to the community effort by pe in power, during the time felt tough and hamper SMEs to obtain business licenses. To accelerate the process of service management that permits to cut the chain of bureaucratic services and organizational units involved. The refinement process must be integrated, crossagency, cross-sector, and coordinated by a single government agency that has the competence and authority to take final overlapping policy sessions, reduce procedural rules, and rationalize government institutions (Workshop on the licensing management system in the economic sector 2007).

In response to this Licensing Implementation of the theory used is the theory of welfare state, the theory of law functions, the theory of licensing, and theory region autonomous.

\section{Grand Theory: Theory of a Welfare State}

The broad outline of the welfare state refers to an ideal model of development that is focused on increasing welfare through giving a more important role to the state in providing universal and comprehensive social services to its citizens. for example, it states that the welfare state "... stands for the developed ideal in which welfare is provided comprehensively by the state to the best possible standards" (Kaelan, 2010).

In the UK, the concept of a welfare state is realized as an alternative to pitching toward the Poor Law that often leads to stigma, because it is only intended for members assistance to the poor (Spicker, 2002). Economic and social development is very important for increasing the level of welfare. Therefore, economic development is closely related to social development. However, economic development is not synonymous with social development. Both have different approaches and goals, although there are intersections. Moreover, the relationship between economic growth and social development is not automatic.

\section{Theory of Legal Functions}

Legal function according to Roscoe Pound (http://lib.ui.ac.id/opac/ui/detail.jsp?id=79780\&/okasi=lo cal) is a critical reflection of Roscoe Pound's thoughts about law, in particular the definition of law and the function of law. To understand Pound's thinking about the law so that in its application it can be used with caution. Roscoe Pound's idea about the legal function 
is based on the understanding ten tang law. For Pound, the law is not only a set of systems of regulations, doctrines, and rules or principles, which are made and promulgated by the competent body but also the processes that manifest the law in a real way through the use of power. Based on this definition of law, Pound put forward his ideas about the function of law as a tool of social engineering. For the law to perform its function, Pound has made a list of interests. The list is a classification of interests consisting of (1) Public interests; (2) Social interests; (3) Individual interests (individual interests). JP Glastra van Loon stated that the function of law is: (Soeroso, 2006)

a. Ordering society and social arrangements;

b. Resolving disputes;

c. Maintain and maintain order and rules, if necessary by force;

d. Changing the order and regulations to adapt to the needs of society;

e. Justice and legal certainty by way of realizing the above functions. Sjachran Basah argues that the function of law in people's lives, especially in Indonesia, has five functions (Rawls, 2011):

1) Directive, as a guide in building to shape the society to be achieved by the goals of state life;

2) Integrative, as a builder of national unity;

3) Stability, as a caretaker (including the results of development) and guardian of harmony, harmony, and balance in the life of the state and society;

4) Perfective, as a complement to the actions of state administration, as well as the attitude of citizens' actions in the life of the state and society;

5) Corrective, both for citizens and the state administration in getting justice.

In other literature, it is stated that the function of law is:

a) As a means of public order and order;

b) As a means of realizing social justice, both physically and mentally; c) As a means of driving development;

d) As critical of the law.

\section{Middle Range Theory: Licensing Theory}

The license is one of the State administrative law instrument that can be used for law enforcement personnel to take legal action in their official duty. Although Syahran Basah admits how difficult it is to define licensing due to the too various definitions of these definitions, the keywords that can be used as a reference for permission are in the opinion of the author, that the act of departure is permitted by legal provisions (Hadjon, 1993).

Regarding licensing, the domain of State administrative law regulates it, because this law regulates the ways of carrying out the duties (rights and obligations) of the power of state equipment. State Administrative Law learns about licensing because permission is a relationship between the government and the community. Permission must be requested in advance from the person concerned to the government through a procedure that has been determined by statutory regulations. The meaning of the word "people" here, is the people in the true sense or people in an RTI artificial person who is a legal entity (The laws and regulations in Indonesia based on Law number 12).

In the case of licensing, it is the administrative officer who has the authority to issue a permit, the relation is to the government's duty in providing public services to the community. In terms of licensing services, permits are a form of service that must be provided to the public in the form of administrative services, namely services that produce various forms of official documents required by licensing. Permits can be in the form of written and/or not written, but in State Administrative Law permission must be in writing, the relation is that if something happens that is not desired, then the permit in the form of a state administrative decision (beschicking) can be used as evidence in court. A license in the form of beschiking, of course, has concrete characteristics (the object is not abstract, but tangible, certain, and determined), individual (who is granted permission), final (someone who already has the right to perform a legal action by its contents which can definitively be gives rise to certain legal consequences). The elements in the permit are the parties, the object of regulation, the ratification, and the issuing party: the period (no permit is valid for life), for 
what time the permit is used, and the reason for issuing the permit; attribution, delegation, and mandate.

Terms of Licensing Certificate. Requirements for the validity of a license are that it must be following the spatial plan, public opinion, as well as the considerations and recommendations of the competent official relating to the business and/or activity, the authority issued, can be in the form of attribution, delegation, mandate.

Freies Ermessen said that the granting of authority or independence to state administration in the HAN system is known as freies ermessen or discretionary power.

\section{Applied Theory: Regional Autonomy Theory}

The notion of regional autonomy inherent in the existence of regional government is also closely related to decentralization. Both regional government, decentralization, and regional autonomy, are part of a policy and practice of government administration, the goal is for the realization of an orderly, advanced, and prosperous community life, every ordinary person lives calmly, comfortably, naturally due to the convenience of all things in the field. society service (Parjoko, 2002). Therefore the need for autonomy at the local level is essential to minimize central government intervention in the regions. In union state (unitarism) regional autonomy had given by the government of the center (central government), while the local government only accepted the surrender of the central government (Sarundajang, 1999). Unlike the case with regional autonomy in federal states, where regional autonomy is inherent in the states.

Normatively, submission to the authority of the central government to other parties (local governments) to be implemented is called decentralization. Decentralization as a system used in government systems is the opposite of centralization. In a centralized system, government authority, both at the central and regional levels, is centralized in the hands of the central government (Soetijo,1990).

The importance of law enforcement licensing for ease of doing business, realized together that the impact is felt on a high-cost economy, business opportunities, and the certainty of trying to be low if it is weak in taking action against violations by SMEs (International Finance Corporation 2006).

From the description above, business licensing is one of the important components for developing a business. However, it is precisely this component that is difficult to access or obtain by the business world, including SMEs (Small and Medium Enterprises) in North Sumatra. Except in districts/cities that have implemented an Integrated Licensing Service System or one-stop service, such as Serdang Bedagai District, which already have KPT (Integrated Licensing Office). In the Study on Integrated Licensing Services for UKM players, around 250 SMEs in 13 Regencies / Cities in North Sumatra, it is clear that various problems faced by business actors are revealed in obtaining business legality (permits). Starting from the high cost of a long time and complicated procedures, it is one of the factors that the small number of SMEs has legality. This study also reveals that SMEs generally do not mind paying fees, of course, provided that the costs incurred must be transparent or by the rates stated in the Regional Regulations.

Because from the study it was also revealed that so far the SMEs have to pay more, 3 to 10 times the official cost. Not to mention the processing time which can reach 15 to 90 days. The tariff is unreasonable and takes a long time, usually applies in districts/cities, which have not implemented an integrated licensing service or one-stop service. Medan Municipality in North Sumatra Province, which has been running the Integrated Licensing Service system for more than 1 year, has shown positive developments. Not only in terms of ease of accessing licenses at low cost and short time, but it also has a positive impact on increasing awareness of SMEs Medan City in processing business permits. This study recommends that the Integrated Licensing Service system should be implemented in all districts. Meanwhile, the Integrated Licensing service system in Medan City and Serdang Bedagai Regency can be an example of the licensing service system in Regencies / Cities in North Sumatra.

For SMEs, licensing has an important meaning as evidence (documents) of the formal legality of their business, especially when the said business actor is going to have a relationship with a business partner or bank. On the other hand, licensing is an important component for MSMEs in conducting their business in a conducive way. The Integrated Licensing Service System or One-Stop Service is the hope of MSME actors to overcome the complexity and expensive licensing process that has occurred so far. This licensing service will not only encourage and benefit MSME players but will also have a positive impact on the Regency / City in increasing region income) from user fees, regional taxes, and in overcoming 
unemployment rates. The long bureaucracy is no longer appropriate to defend. Current economic activities have made business actors dynamic and able to compete with other business actors. If the regions want to advance, then this condition must also be followed by a paradigm shift in the bureaucracy that has been authorized to run licensing services.

The findings and recommendations from the study of integrated licensing services for MSMEs in North Sumatra, are as follows:

1. The implementation of licensing bureaucracy in regencies/cities in the province of North Sumatra has not been going well and is still a complaint among MSME actors.

2. Licensing still goes through many places, in other words not at one location, because each agency has the authority to issue permits independently and separately.

3. Licensing financing is still considered expensive and far above the tariff stated in the Perda (Regional Regulation) as a result of the widespread illegal fees outside the applicable tariff provisions.

4. The process of obtaining permits is still convoluted and difficult.

5. Time of obtaining a license to be longer than it should because is not the maintenance of operational standards for each type of license.

6. Integrated Licensing Service System or OneStop Service, is the best choice at this time, to address complaints from MSME actors.

After studying the results of the above studies, the North Sumatra Province Research and Development Agency hereby recommends the following:

1. The North Sumatra Provincial Government needs to immediately encourage the Regency / City to improve its licensing service system to be simpler, cheaper, faster, and more transparent.

2. The North Sumatra Provincial Government needs to stipulate that the Integrated Licensing Service System or One-Stop Service becomes the standard for the licensing service system in effect in the Regency / City.

3. The government of North Sumatra Province needs to increase outreach activities regarding the Integrated Licensing Service System or OneStop Service, both to related government officials and to the MSME community.

4. The Provincial Government of North Sumatra needs to carry out training to improve human resources for officers (employees) serving licensing at the Regency / City level.

5. The North Sumatra Provincial Government needs to provide incentives to improve the welfare of officers (employees) serving licensing at the Regency / City level.

6. The North Sumatra Provincial Government needs to encourage the creation of a conducive climate for MSMEs in the regions in carrying out their business activities.

So far, licensing management of small and medium enterprises (UKM) has not been fully implemented according to existing regulations, some are still managed by related agencies, even though there is still cooperation between licensing management agencies in the process of completing the application file which ultimately makes it difficult for licensing applicants. If the government hopes to streamline and streamline the completion of the process by using technological means such as the e-permit program with factors that are considered, including shorter time, cheaper, and avoidance of brokers, then this hope cannot be fully achieved, let alone the process. completing the application file manually will be slower to achieve the existing expectations because in North Sumatra Province only Medan City uses licensing service facilities that use Local Area Network (LAN) level technology facilities.

In Medan City the integrated one-stop licensing program is based on the decision of the head of the Medan City Integrated Licensing Service Agency number: 800/12124 dated December 30, 2010, regarding changes to the decision of the head of Medan City Integrated Licensing Service Agency number 800/0120 concerning the establishment of standard operating licensing procedures which become the authority of the Medan city integrated licensing service agency. However, various types of permits that should have been carried out under one roof and integrated until now have not yet been realized due to the delegation of authority of the Medan mayor to related agencies in completing community permit applications. 
Some of the agencies referred to are: for building permits (IMB), which is still managed by the Head of the Spatial Planning Service, licensing for billboards attached to walls is still managed by the Regional Revenue Service (Dispenda) which is still independently managed by Head of the Spatial Planning and Building Administration (TRTB), for cloth banners, the permits are managed by the One-Stop Integrated Licensing Agency (BPTSP), entertainment/crowd licensing, restaurants, hotels, discos, and parking are managed by the Tourism and Culture Office in cooperation I'm with DISPENDA. With the licensing procedures as described above, it seems that they are overlapping, causing confusion among the people applying for permits. Things like this have happened to other regencies and cities in North Sumatra Province, including the Small Medium Enterprises (SME) licensing.

\section{LAW ENFORCEMENT OF SME LICENSING IN ABUPATEN AND CITIES IN NORTH SUMATERA PROVINCE.}

Law enforcement is aimed at improving legal order and certainty in society. This is done to curb the functions, duties, and powers of the institutions that are tasked with enforcing the law according to the proportion of their respective scope and based on a good cooperation system and supporting the objectives to be at the accomplishment (Sanyoto, 2008).

According to Satjipto Raharjo law enforcement is essentially the enforcement of ideas or concepts about justice, truth, and benefits.

Social, and so on. So law enforcement is an attempt to bring these ideas and concepts into reality. In essence, law enforcement embodies values or principles that contain justice and truth, law enforcement is not only the duty of law enforcers who are known conventionally, but it is the duty of everyone. However, about public law, the government is responsible.

Licensing law enforcement SMEs in North Sumatra province must still need to be improved because many fax tor-factors that cause mainly there is cultural disease community and law enforcement officials. In general in North Sumatera the term "SUMUT" or "reality all the affairs of using cash" and "Hepeng do namangatur nagaraon", so already entrenched that the role of money can solve the problems of the state this even though the law still violated so that the culture is very hampering enforcement of the licensing law in particular.

\section{a. Form of Violation}

The form of violations by SME entrepreneurs originated from the difficulty of licensing entrepreneurs who seemed convoluted and expensive. The high cost is not due to the target that must be paid according to the existing provisions because there are still other money expenses for various reasons in the licensing service. Forms of violations include non-completion of operational licensing decisions so that many have an impact on environmental impact analysis (AMDAL) and even many businessmen are reluctant to take care of licensing because they are considered classic and boring in terms of procedures, costs, time, and services.

\section{b. Actions are taken by the Local Government in Dealing with Violations of SME Licensing}

If there is a violation, the agency authorized to issue a license to give a warning and call the relevant officials to be able to resolve the problem according to the procedure and even be subject to criminal action, but there are still many non-existence between related agencies and business closures are carried out by parties who are not directly authorized to do so shut down the company. One example is in the cultivation of C mineral in the area of Sawit Seberang District, Langkat Regency, North Sumatra. The local police apparatus closed the complaint by the local police without communicating with the agency authorized to issue permits, namely the Integrated Licensing Service and the Mining and Energy Office of Langkat Regency.

This is due to the weak supervision of the agencies involved in the operations of entrepreneurs and still unable to implement the functions and duties of the local police apparatus. This generally occurs in North Sumatra Province in regencies and cities due to the lack of knowledge of entrepreneurs about the law, the functions, and roles of law enforcement officials who should be in charge of dealing directly with permit violations. The crux of the problem is that the community only understands that when police officers come to their place of business, all must be followed without knowing other institutions that are more competent. From the conditions felt by the SME community to create a conduciveness, SME entrepreneurs hope that law enforcers and competent agencies are professional in carrying out actions.

Law enforcement on SME licensing is a major factor in improving the populist economybecause, with the 
application of good and correct law, the level of community business will progress and develop to avoid actions against the law. The condition of the people of North Sumatra, in general, is still less concerned with actions against the law as evidence of many state officials who have become defendants and have been convicted of their behavior, attitudes, and actions against the law.

With conditions like this, it is natural that many people still behave in violating the law, including SME entrepreneurs, especially people in the North Sumatra region. Therefore, to get to the welfare of the community in the business of economic activity, the community in the field of SMEs must obey the law and the community itself must be aware and obey the applicable regulations, but the government should be firm in enforcing licensing law. This is to enforce the licensing law concretely so that the people's economy can progress and develop.

Efforts were taken by SME Licensing Law Enforcement in North Sumatra Province in improving the people's economy in the region.

Efforts to enforce the SME licensing law in North Sumatra Province in improving the people's economy in the region take directions and policies, including:

1. Enforce the Minister of Home Affairs Regulation No. 24 of 2006 concerning One-Stop Integrated Licensing Service

2. Implementing the Decree of the Minister of PAN No.63 / KEP / M.PAN / 7/2003 concerning General Guidelines for the Implementation of Licensing Services, in the process of improving systems and procedures for service institutions

3. Enacted the Governor of North Sumatra Regulation Number 37 the Year 2011 concerning the delegation of licensing service authority to the Integrated Licensing Service Agency for the benefit of the community, and applied to all districts/cities in the entire North Sumatra Province following the authority of the local regional head.

4. Provide strict sanctions against elements of licensing services that violate applicable regulations.

5. Reducing transaction costs and high-cost economic practices for both the start-up and business operations stages.
6. Its main activities are completing the deregulation (trimming of bureaucracy) regulations, and business licensing procedures, developing service implementing agencies, and implementing one-stop and one-stop integrated licensing services.

7. Arranging clear rules for cutting bureaucracy in licensing procedures and business management with the principles of transparency and good governance.

8. Arranging clear rules of the game, trimming the bureaucracy with the principles of transparency and good governance.

9. Ensure business certainty and improve law enforcement, and protect the rights of economic actors.

10. Improve the harmonization of national and regional laws and regulations, by prioritizing the principles of legal certainty, deregulation, and efficiency in costs and management time.

11. Establish standardization of work facilities and infrastructure, one-stop or one-stop integrated services.

North Sumatra Provincial Government Needs to Understand General Guidelines for the Implementation of Licensing Services and their implications are as follows:

1. The essence of licensing services

2. Is the provision of excellent service to the community which is a manifestation of the obligations of the government apparatus as public servants

3. The principle of licensing services

a. Transparency

b. Accountable

c. Conditionally

d. Participative

e. Equal Rights

f. Not discriminatory in the sense of not differentiating ethnicity, race, religion, class, gender, and economic status. 


\section{g. Balance}

4. The fundamental of licensing services

a. simplicity.

It's straightforward, easy to understand, and easy to implement

b. Clarity.

1) Technical and administrative requirements for licensing services.

2) The work unit/official who has the authority and responsibility in provide services and, completion complaint/issues/disputes in lateness service delivery licensing late.

3) Details of licensing service fees and payment procedures.

c. The certainty of time.

d. Can be completed within the set time

e. Accuracy Products licensing service of an accepted right, and right.

f. The Security early, process, and product licensing services provide security and legal certainty.

g. Responsibility, Leadership licensing service providers or the designated official responsible for the provision of services and resolution of complaints/problems in lateness service licensing delivery.

h. Completeness of Facilities and Infrastructure, the availability of adequate work facilities and infrastructure, work equipment, and other supporting facilities, including the provision of telecommunications and information technology facilities.

i. Ease of access, Temp at, location, and service facilities are adequate, easily accessible by the public, and can take advantage of information and communication technologies.

j. Discipline, politeness, and friendliness. Service providers must be disciplined, polite and polite, friendly, and provide service sincerely.

k. Comfort, service environment must be orderly, orderly, provided a waiting room that is comfortable, clean, tidy, a beautiful and healthy environment

5. Service standards for licensing delays.

The operation of licensing services must have service standards and be licensed as a guarantee of certainty for service recipients. The service standard is a measure needed and must be obeyed by service providers and or recipients.

Service standards include at least :

a. Service Procedure.

b. Standardized for service providers and recipients, including complaints.

c. Completion Time.

d. Determined from the time the application is submitted to the completion of services, including complaints.

e. Service Fee.

f. Service fees/rates including the details that are determined in the service delivery process.

g. Service Products. Service results to be received are by the stipulated conditions.

h. Facilities and Infrastructure Provision of service facilities and infrastructure

i. adequate by the providers of care per permit late.

j. Service Provider Competence.

k. The competence of the service provider must be properly determined based on the knowledge, expertise, skills, attitudes, and behavior required.

6. Implementation Patterns Licensing Services

1) Functional licensing service patterns are provided by service providers, by their duties, functions, and authorities.

\section{2) Centralized}

Licensing service patterns are provided singly by service providers based on the delegation of authority from other relevant service providers

3) Integrated 


\section{a) One-Stop Integrated}

The one-stop integrated service pattern is held in one place which includes various types of services that do not have a related process and are served through several doors. Regarding the types of services that are already close to the community, it does not need to be unified.

b) One Door Integrated

The one-door integrated service pattern is held in one place which includes various types of services that have a related process and are served through one door.

\section{4) Task Force}

Licensing service officers individually or in the form of a task force are assigned to certain service providers and service locations. In addition to these service patterns, agencies that carry out-licensing services can develop their service delivery patterns to find and create service improvement innovations.

Licensing Service Fees Determining the amount of licensing service fees needs to pay attention to the following matters:

a) The level of ability and purchasing power of the community;

b) Value / price applicable to goods and or services;

c) Details of the cost must be clear on the type of delay in licensing services that require action such as research, inspection, measurement, and testing.

d) Determined by an authorized official and observes procedures in accordance with the provisions of laws and regulations. Services for Persons with Disabilities, Elderly, Pregnant Women and Toddlers.

e) Service providers are obliged to make efforts to provide the necessary facilities and infrastructure as well as provide special access in the form of easy services for the condition of their communities.

\section{Level of Community Satisfaction}

Measuring the success of service delivery is determined by the level of satisfaction of service recipients. Service recipient satisfaction is achieved when service recipients obtain services as needed and expected. Therefore, every service provider conducts a survey on the community satisfaction index periodically.

Supervision of Complaints and Disputes Supervision of the implementation of SME licensing services is carried out through:

a) Inherent supervision, namely supervision carried out by a direct superior in accordance with the provisions of laws and regulations.

b) Functional supervision, namely supervision carried out by the functional supervisory apparatus in accordance with the provisions of laws and regulations

c) Community supervision, namely supervision carried out by the community, in the form of reports or complaints.

8. Complaint and Dispute Resolution

a) Complain

b) Disputes in the event that the complaint cannot be resolved by the licensing service provider concerned and a dispute occurs, the settlement can be done through legal channels

\section{CONCLUSION}

The implementation of SME licensing in North Sumatera Province has not been going well and maximally, in fact, there are still many SME entrepreneurs who complain about bureaucracy and do not have a permit showing that it does not have a direct effect on improving the people's economy because the local government has not been able to implement the rules as expected. So far, licensing management of small and medium enterprises has not been fully implemented by existing regulations, some are still managed by related agencies, even though there is still cooperation between licensing management agencies in the process of completing the application file which ultimately makes it difficult for licensing applicants. If the government hopes to streamline and streamline the completion of the process by using technological means such as the e-permit program with factors that are considered, including shorter time, cheaper, and avoidance of brokers, then this hope cannot be fully achieved. 
SME licensing law enforcement in North Sumatera Province still needs to be improved because many factors are causing it, especially the existence of cultural diseases of the community and law enforcement officers. In general, in North Sumatra, the term "SUMUT" or "has become a reality in all matters using cash " and " Hepeng do namangatur nagaraon", so it is a culture that the role of money can solve the country's problems even though the law is still violated so this culture is very inhibiting licensing law enforcement in particular. This study is expected to provide input for the licensing process for small businesses so that they can support their economy. For further studies, there is a need for a study regarding this licensing with the enactment of the employment creation law and during the Covid 19 pandemic.

\section{REFERENCES}

Based on the results of a study by the World Bank's International Finance Corporation (IFC) in 2006, Indonesia's ranking decreased from 131st in 2005, to 135th in 2006,

Eman, a mining operator in the area of Sawit Sebrang District, Langkat Regency, North Sumatra Province.

http://analisadaily.net/news/re ad / rapor-red-service-public-pemprovNorth Sumatra accessed on April 9, 2014 at 16.29 WIB).

http://lib.ui.ac.id/opac/ui/detail.jsp?id=79780\&lokasi=local : Melkias Hetharia Document Description

Iman Jauhari, Monograph of Legal Research Methodology, Postgraduate Program at the Islamic University of Bandung. 2013.

John Rawls, Theory of Justice, Institutions and formal justice, Pustaka Pelajar, Jogjakarta , 2011, HIm. 65.

Johnny Ibrahim, Teori, Metode dan Penelitian Hukum Normatif, Bayu media Publising, Malang: Jawa Timur, 2007, HIm. 300

Johnny Ibrahim, Teori, Metode dan Penelitian Hukum Normatif, Bayu media Publising, Malang: Jawa Timur, 2007, HIm. 300.

Kaelan, Pendidikan Pancasila, Tujuan Negara pada Aleniake IV PembukaanUndang-Undang Dasar 1945, Paradigma Jogjakarta, 2010. HIm, 164.

Neni Sri Imaniyati, Hukum ekonomi dan Hukum Islam Dalam Perkembangan. Prespektif Hukum Ekonomi dan peran hokum adalah dalam pembangunan nasional, MandarMaju. Bandung, 2002, HIm. 1

Parjoko, Regional Autonomy Philosophy Associated with the Implementation of Law Number 22 Year 1999, Number 25 Year 1999, paper, Papers of Science Philosophy (Pps 720) Postgraduate / Doctoral Program Bogor Agricultural University, February, 2002, p. 1. https://doi.org/10.1177/019145379902500102

Philipus M. Hadjon, Introduction to Licensing Law ,Yuridika, First Edition, Surabaya , 1993, Pg. 2

R. Soeroso. Introduction to Law, Role and Function Introduction to Law, Sinar Grafika, Jakarta, 2006, p. 9.

Sanyoto, Law Enforcement in Indonesia, Journal of Law Dynamics Faculty Of Law Univ. General Sudirman.Vol. 8 No.3 (2008)

Sarundajang, The Backflow of Central Power to the Regions, Pustaka Sinar Harapan, Jakarta, Prints 1, July, 1999, p. 56.

Sedarmayanti \& Syarifudin Hidayat, Metodologi Penelitian, CV. Mandar Maju: Bandung, 2002, HIm. 23

Soetijo, Central Government Relations and Local Government, PT Rineka Ripta, Jakarta, 1990, p. 78.

Spicker, "Teori Feminis dan Social Work”, makalah yang disampaikan pada Workshop on Feminist Theory and Social Work, Pusat Studi Wanita, Universitas Islam Negeri (UIN), Sunan Kalijaga, Yogyakarta 13 April 2002.

Sulistyani Eka Lestari, Hardianto Djanggih,Urgensi Hukum Perizinan Dan Penegakannya Sebagai Sarana Pencegahan Pencemaran Lingkungan Hidup, Jurnal Masalah-Masalah Hukum Jilid.48 No.2 April 2019 https://doi.org/10.14710/mmh.48.2.2019.147-163

Sunaryati Hartono, Pengantar IImu Hukum. Apakah The Rule of Law, Bandung: Alumni, 1976 Bandingkan dengan Kaelan dan Ahmad Zubaidi, Pendidikan Kewarganegaraan, The Rule Of Law dan HakAsasiManusia, Paradigma, Jogjakarta, 2007, HIm. 94

The laws and regulations in Indonesia based on Law number 12 of 2011 are: UUD 1945, MPR Decree, Law/Perpu, Government Regulations, Presidential Regulations and Regional Regulations: Provinces and Regencies/Cities.

Workshop on the licensing management system in the economic sector, in North Sumatra Province, on May 11, 2007 . Efforts to achieve the goals and objectives are carried out through: Improving laws and regulations in the business sector; Simplification of business service procedures; Strengthening of institutions and authorities; Information system development.

Yesmil Anwar \& Adang, Hukum Tak Pernah Tidur; Pergulaan Antara Manusia dan Hukum dalam Jagat Raya Yang Penuh Keteraturan, KP2W-Puslit: Bandung, 2010, HIm. 136.

Received on 02-01-2021

Accepted on 26-01-2021

Published on 22-02-2021

\section{DOI: https://doi.org/10.6000/1929-4409.2021.10.59}

(C) 2021 Mukidi et al.; Licensee Lifescience Global.

This is an open access article licensed under the terms of the Creative Commons Attribution Non-Commercial License (http://creativecommons.org/licenses/by-nc/3.0/) which permits unrestricted, non-commercial use, distribution and reproduction in any medium, provided the work is properly cited. 